\title{
СИНТЕТИЧЕСКИЕ СИЛИКАТЫ КАК ПЕРСПЕКТИВНАЯ ГРУППА МАТЕРИАЛОВ ДЛЯ ИЗВЛЕЧЕНИЯ МИКРООРГАНИЗМОВ ИЗ ВОДНЫХ СРЕД
}

\author{
С.Б. Ярусова, С.Н. Сомова, У.В. Харченко, П.С. Гордиенко \\ Институт химии Дальневосточного отделения Российской академии наук, \\ 690022, Россия, Владивосток, пр.100-летия Владивостока, 159.
}

\section{DOI: 10.19163/MedChemRussia2021-2021-413}

E-mail: yarusova_10@mail.ru

Известно, что различные кремнийсодержащие соединения (глины, высокодисперсный диоксид кремния и др.) являются основой многих лекарственных препаратов [1]. Научные исследования в области синтеза силикатов в настоящее время проводятся достаточно активно, поскольку природные аналоги данных соединений не всегда соответствуют требованиям, предъявляемым к ним по химическому составу и функциональным свойствам.

Авторами синтезированы наноструктурированные аморфные и кристаллические силикаты и алюмосиликаты щелочных и щелочноземельных металлов с удельной поверхностью $100-320 \mathrm{~m}^{2} / г$ - гидросиликаты кальция $\mathrm{nCaO} \cdot \mathrm{mSiO}_{2} \cdot \mathrm{pH}_{2} \mathrm{O}$ [2] и алюмосиликаты калия с заданным соотношением Si/ $\mathrm{Al}\left(\mathrm{Me}_{2} \mathrm{Al}_{2} \mathrm{Si}_{\mathrm{x}} \mathrm{O}_{\mathrm{y}} \cdot \mathrm{nH}_{2} \mathrm{O}\right.$, где $\left.\mathrm{x}=1-5, \mathrm{y}=2(\mathrm{x}+2) ; \mathrm{Me}-\mathrm{K}\right)$. Проведено исследование сорбционных свойств полученных соединений относительно тестовых культур микроорганизмов Escherichia coli и Bacillus subtilis.

В результате исследований установлено, что наибольшая сорбционная емкость наблюдается по отношению к бактериям Escherichia coli для исследуемых соединений. Эффективность сорбции E. coli через 60 мин достигает 82\% для гидросиликатов кальция и $86 \%$ для алюмосиликатов калия. Эффективность сорбции B. subtilis не превышает $52 \%$ как для гидросиликатов кальция, так и для алюмосиликатов калия. Для препарата «Белый уголь», используемого в качестве образца сравнения, получены аналогичные закономерности. Однако эффективность данного препарата по отношению к E. coli ниже по сравнению с алюмосиликатами калия с определенным соотношением Si/Al и не превышает $70 \%$.

Дальнейшие исследования взаимосвязи условий синтеза, состава, структуры исследуемых силикатных сорбентов с их свойствами важны для выработки практических рекомендаций по применению в процессах микробиологической очистки водных сред.

\section{Литература}

[1] В.Н. Панфилова, Т.Е. Таранушенко, Педиатрическая фармакология. 2012. № 6, Т.9. С. 34-39.

[2] С.Б. Ярусова, С.Н. Сомова, П.С. Гордиенко, У.В. Харченко, И.А. Беленева, Материалы Шестого междисциплинарного научного форума с международным участием «Новые материалы и перспективные технологии», г. Москва, 23-27 ноября 2020 г. 2020. Т.ІІ - М.: Центр научно-технических решений (АНО ЦНТР), 2020 г. С. 223-226. 